\title{
Large African Hive Beetle Oplostomus fuligineus (Olivier) (Insecta: Coleoptera: Scarabaeidae) ${ }^{1}$
}

\author{
Worrel Diedrick and Cameron Jack ${ }^{2}$
}

\section{Introduction}

Oplostomus fuligineus (Olivier), often referred to as the large African hive beetle (Oldroyd and Allsopp 2017), is a common pest of honey bee colonies (Apis mellifera) in sub-Saharan Africa (Figure 1) and poses a possible risk to US colonies if it were to invade. Oplostomus fuligineus feeds on honey bee brood and is capable of causing significant damage to colonies (Oldroyd and Allsopp 2017). It belongs to the scarab subfamily Cetoniinae in the tribe Cremastocheilini, which is known for its many predatory species. The beetle is often confused with a similar species, Oplostomus haroldi (Witte), which has the same common name.
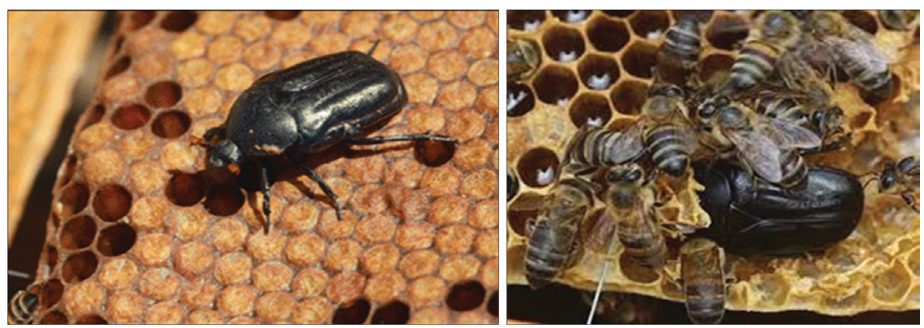

Figure 1. Adult large African hive beetles, Oplostomus fuligineus (Olivier), on honey bee comb.

Credits: B. Oldroyd, University of Sydney

\section{Distribution}

Oplostomus fuligineus has been reported in Senegal,

Nigeria, Kenya, Zambia, Namibia, Botswana and six South African provinces (Oldroyd and Allsopp 2017). This species prefers dryer grazing land where dung is abundant, but it is absent in very dry areas like the Kalahari Desert in Botswana.

\section{Description}

\section{Eggs}

Freshly laid eggs look like white ovals (2.1 mm long) and grow into larger spheres ( $2.8 \mathrm{~mm}$ long) as water is absorbed during development (Donaldson 1989).

\section{Larvae}

Newly hatched larvae are soft with white head capsules (1.8 to $2.0 \mathrm{~mm}$ wide) that turn brown in a few hours, matching the brown setae and spiracles (Donaldson 1989). There are three larval instars. In last instar larvae, the head is orange with dark eyes, measuring $5 \mathrm{~mm}$ in width, with eight prominent spiracles on the abdomen. The segments are greatly swollen at the end of the abdomen, making the larvae appear pear-shaped (Figure 2). These larvae resemble larvae of other tribes of Cetoniinae.

\section{Pupae}

Newly formed pupae are creamy white but become a light reddish-brown color before eclosion (Donaldson 1989).

1. This document is EENY-763, one of a series of the Entomology and Nematology Department, UF/IFAS Extension. Original publication date July 2020. Visit the EDIS website at https://edis.ifas.ufl.edu for the currently supported version of this publication. This document is also available on the Featured Creatures website at http://entomology.ifas.ufl.edu/creatures.

2. Worrel Diedrick; and Cameron Jack, lecturer; Entomology and Nematology Department, UF/IFAS Extension, Gainesville, FL 32611.

The Institute of Food and Agricultural Sciences (IFAS) is an Equal Opportunity Institution authorized to provide research, educational information and other services

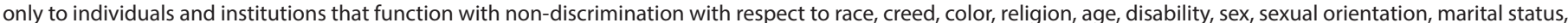

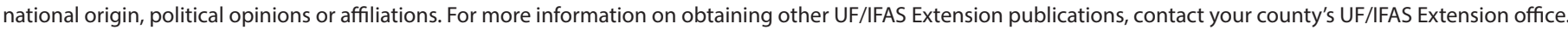
U.S. Department of Agriculture, UF/IFAS Extension Service, University of Florida, IFAS, Florida A \& M University Cooperative Extension Program, and Boards of County Commissioners Cooperating. Nick T. Place, dean for UF/IFAS Extension. 


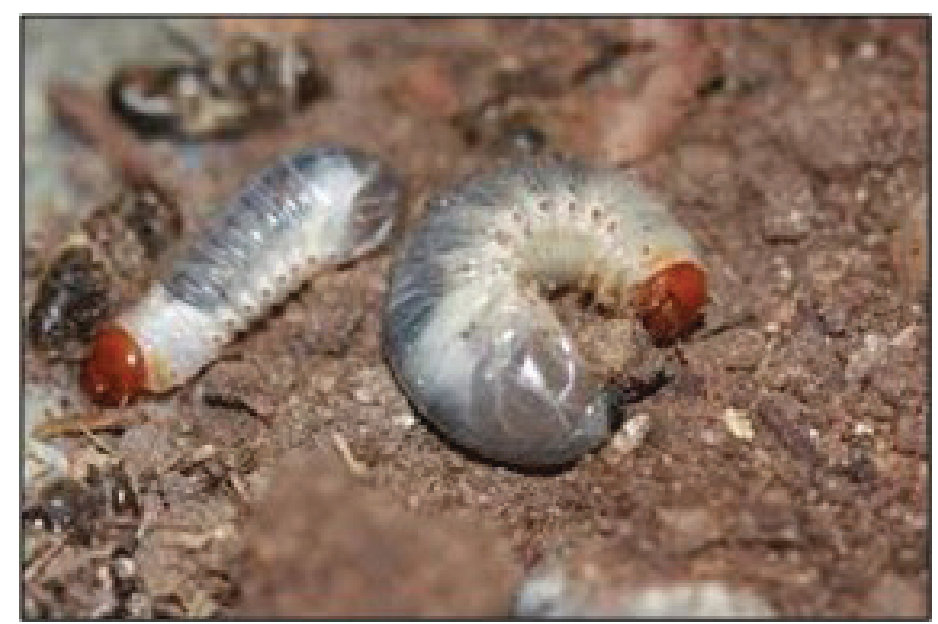

Figure 2. Larvae of large African hive beetle, Oplostomus fuligineus (Olivier), (left) second instar, (right) third instar.

Credits: B. Oldroyd, University of Sydney.

\section{Adults}

Opolostomus fuligineus adults are 20 to $23 \mathrm{~mm}$ in length. They are uniformly black except for the tips of the antennae, which are orange (Figure 3). The antennae are shielded and usually tucked under the head, which prevents biting attacks from bees (Fombong et al. 2012). The terminal segment of the antenna is lamellate (elongated and flattened) (Figure 3). Males and females look alike except that the sternites of the female are more rounded than those of the male. Additionally, males have a groove on abdominal sternites two and three that may extend to sternite four (Donaldson 1989). Opolostomus fuligineus is differentiated from Oplostomus haroldi by the shape of a broad plate at the front of the beetle's head (clypeus). In Opolostomus fuligineus, the clypeus has rounded edges. The clypeus in Opolostomus haroldi has sharp edges, making it rectangular in appearance. Additionally, Opolostomus fuligineus is black (Figure 3), whereas Opolostomus haroldi has a variety of body colors that include all black, black with reddish brown stripes and black with orange stripes (Fombong et al. 2013, Oldroyd and Allsopp 2017).

\section{Life Cycle}

After mating in the bee hive, females leave the hive to oviposit in the dung of herbivorous animals such as cattle and horses, while males apparently remain in the hive (Oldroyd and Allsopp 2017). The total period from oviposition to hatching is usually six to ten days. Toward the end of this period, the sclerotized tips of the mandibles are visible through the egg wall. After hatching, the larvae feed and develop in dung. Larvae take 49 to 66 days (average 55 days) to develop before molting to pupae (Donaldson 1989).

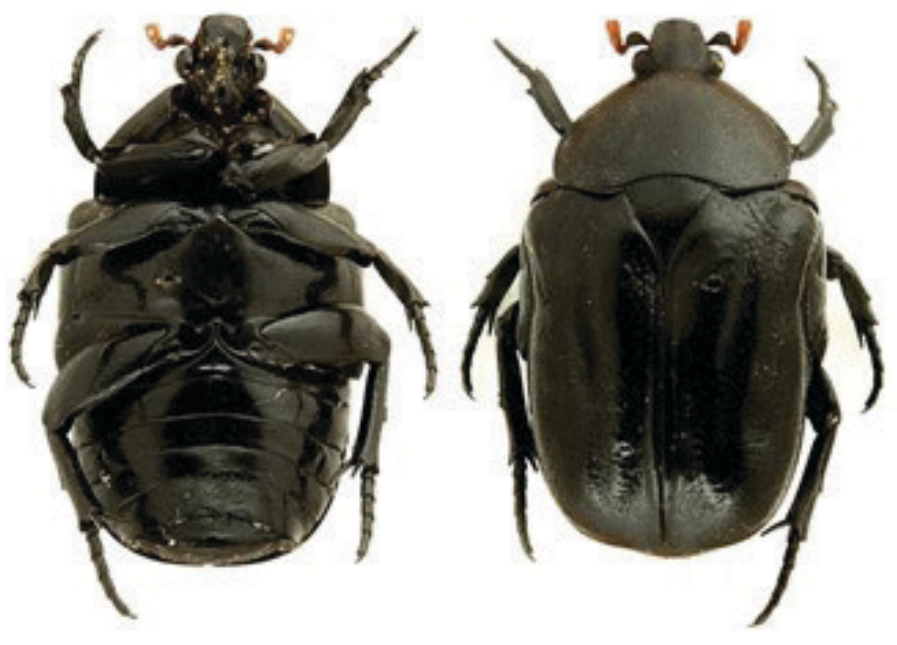

Figure 3. Adult large African hive beetles, Oplostomus fuligineus (Olivier), (left) ventral view, (right) dorsal view.

Credits: J. Dvořák, BioLib.cz

Chambers in the dung enclose the developing cocoons, and dung becomes extremely hard when dry (Figure 4; Oldroyd and Allsopp 2017). The time from pupal formation to adult emergence is 21 to 29 days, but these figures come from laboratory studies. As adults are mostly found from October to March in Kenya, or November to February in South Africa, beetles presumably spend the cooler months as immatures. Adult Oplostomus fuligineus enter honey bee hives and consume the brood (Figure 5), and females require a brood meal to produce eggs. Adults live at least 30 days but probably much longer (Donaldson 1989, Oldroyd and Allsopp 2017).

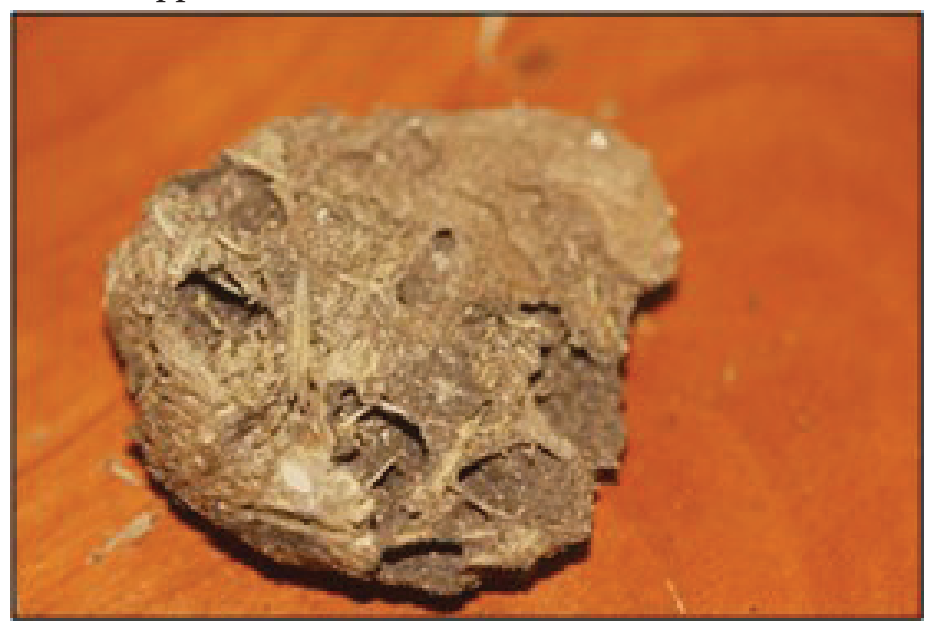

Figure 4. Cow dung with empty cocoons of emerged large African hive beetles, Oplostomus fuligineus (Olivier).

Credits: B. Oldroyd, University of Sydney

\section{Economic Importance}

Heavily infested honey bee colonies can have 700 or more adult beetles (Donaldson 1989, Fombong et al. 2013, Oldroyd and Allsopp 2017). The beetles preferentially feed on young honey bee larvae in soft wax, chewing along the 
midrib of the comb (Oldroyd and Allsopp 2017). In the absence of young larvae, beetles will feed on pupae, honey, or pollen. Oplostomus fuligineus have also been observed under laboratory conditions feeding on grapes and figs (Donaldson 1989). In strong colonies, honey bees rapidly remove dead larvae and repair honey combs, so beetle damage can appear minor even in heavily infested colonies. However, beetles can cause serious damage in weak colonies where access to brood and honey is easy (Figure 5; Fombong et al. 2013).

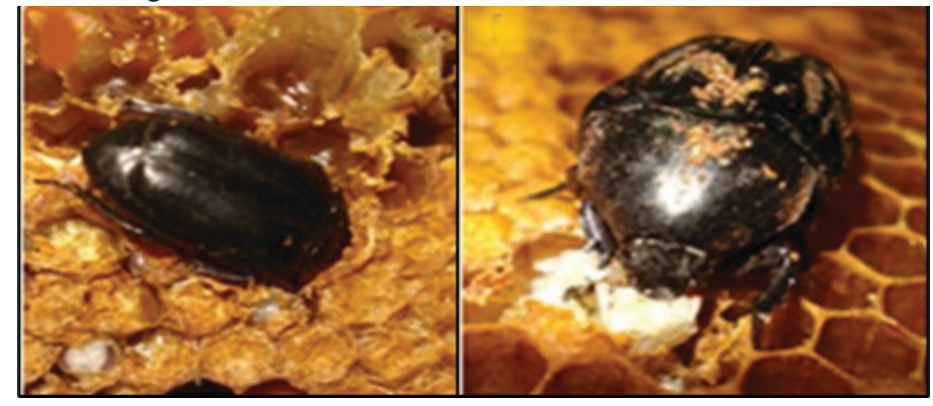

Figure 5. Adult large African hive beetle, Oplostomus fuligineus (Olivier), (left) beetle burrowed deep into comb while feeding on brood, (right) beetle feeding on honey bee brood on comb surface. Credits: A.T. Fombong, International Centre of Insect Physiology and Ecology, Nairobi, Kenya

\section{Management}

Adult Oplostomus fuligineus are strong flyers and enter honey bee colonies to feed on brood and pollen (Oldroyd and Allsopp 2017). Maintaining a strong colony remains the most effective method to reduce the risk of infestation from Oplostomus fuligineus. Moreover, strong colonies are better able to defend the hive entrance and prevent access to the beetles. Regular inspection of colonies for the presence of Oplostomus fuligineus is an important part of prevention. Beekeepers in infested areas are encouraged to inspect their honey bee colonies at least once every two weeks and physically remove and kill beetles.

Wherever these beetles are a problem, beekeepers can install a beetle barrier across the entrance (Figure 6). This prevention method is effective but requires hive bodies that are in good condition with no large cracks or holes (Oldroyd and Allsopp 2017). Fombong et al. (2016) stated that adult beetles are attracted to volatiles emitted by honey bee colonies, creating new possibilities for the development of pheromone traps to incorporate into integrated pest management programs.

Maintaining awareness of Oplostomus fuligineus within colonies is imperative to reducing or eliminating the introduction of the beetle into new geographical regions. If beekeepers fail to identify the beetles before transporting their colonies to other regions, beetles could be introduced into new ecosystems (Oldroyd and Allsopp 2017). In Africa (Donaldson 1989) and in Florida, other scarab beetles are sometimes found in honey bee hives (Euphoria sepulcralis), so any suspected introduction needs to be confirmed.

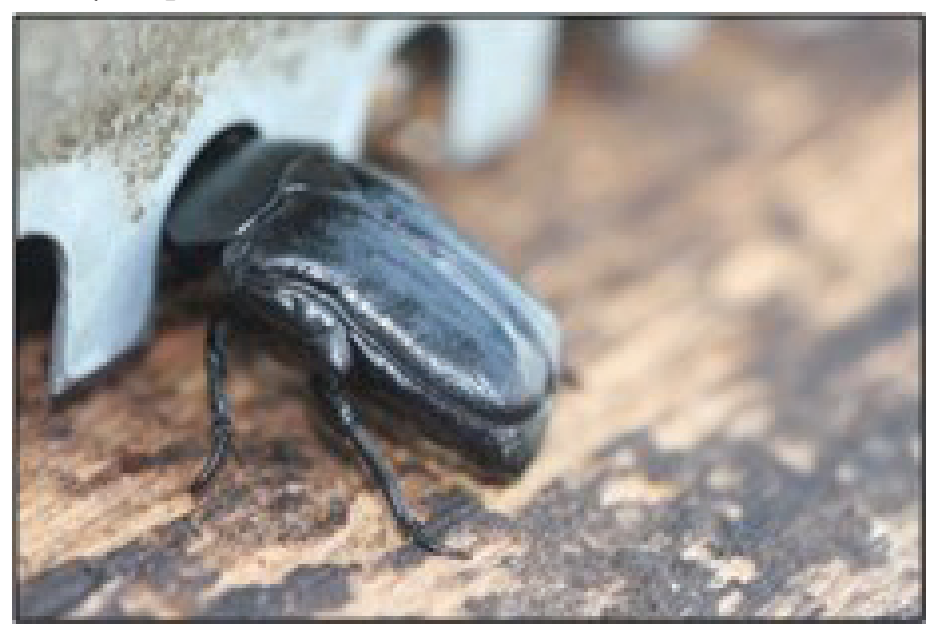

Figure 6. Adult large African hive beetle, Oplostomus fuligineus (Olivier), is prevented from entering a colony by a beetle guard installed by a beekeeper.

Credits: B. Oldroyd, University of Sydney

Unlike another pest of honey bees, the small hive beetle Aethina tumida, Oplostomus fuligineus larvae do not develop in bee colonies. Additionally, most European races of honey bees are unable to create natural entrance barriers from propolis as do many African races of honey bees. Therefore, management of Oplostomus fuligineus should be focused on preventing the adult from entering hives.

The risk associated with an Oplostomus fuligineus introduction into Florida seems minimal. However, if introduced, it could cause damage to honey bee colonies if best management practices are not followed. As Oplostomus fuligineus are believed to overwinter as pupae in dung, Florida's extensive equine and cattle industries could provide abundant habitat for the establishment of the beetle in the state. Furthermore, adult Oplostomus fuligineus can prey on the brood of paper wasps (Clauss 1983, Keeping 1984, Donaldson 1989), which are also abundant in Florida. Thus, the presence of an alternative host to honey bees could potentially enhance the population size of Oplostomus fuligineus should the beetle become established. Failure to prevent Oplostomus fuligineus from entering colonies could lead to rapid spread and establishment of this pest in the United States, as hundreds of thousands of colonies are moved around the country annually to aid the pollination of crops (Calderone 2012).

\section{Acknowledgments}

We thank Ben Oldroyd, Baldwyn Torto and Josef Dvořák for providing us with literature and permission to use their 
photographs of the large African hive beetles in this article. We also thank Janice Peters and Emily Noordyke for their editorial comments.

\section{Selected References}

Calderone NW. 2012. "Insect pollinated crops, insect pollinators and US agriculture: Trend analysis of aggregate data for the period 1992-2009.” PlosONE 7 (5), e37235.

Clauss B. 1983. Bees and Beekeeping in Botswana, Ministry of Agriculture, Gabarone, 122 pp.

Donaldson JMI. 1989. “Oplostomus fuligineus (Coleoptera: Scarabaeidae): Life cycle and biology under laboratory conditions, and its occurence in bee hives." The Coleopterists Bulletin 43: 177-182.

Fombong AT, Haas F, Ddegwa PN, Irungu LW. 2012. "Life history of Oplostomus haroldi (Coleoptera: Scarabaeidae) under laboratory conditions and a description of its third larval instar." International Journal of Tropical Insect Science 32: 56-63.

Fombong AT, Mumoki FN, Muli E, Masiga DK, Arbogast RT, Teal PEA, Torto B. 2013. "Occurrence, diversity and pattern of damage of Oplostomus species (Coleoptera: Scarabaeidae), honey bee pests in Kenya." Apidologie 44: 11-20.

Keeping MG. 1984. "A beetle predacious on the brood of a social wasp." Journal of the Entomological Society of Southern Africa 47: 355-356.

Oldroyd BP, Allsopp MH. 2017a. Risk assessment for large African hive beetle. Research report, Rural Research and Development Corporation, Canberra.

Oldroyd BP, Allsopp MH. 2017b. "Risk assessment for large African hive beetles (Oplostomus spp.) - a review.” Apidologie 48: 495-503. 